BY THE COMPTROLLER GENERAL

$+2$ TEB 81980 Report To The Congress OF THE UNITED STATES

\title{
Geothermal Energy: Obstacles And Uncertainties Impede Its Widespread Use
}

The Government has spent nearly half a billion dollars over the last 5 years for geothermal energy development, but numerous economic, technical, and other obstacles and uncertainties have impeded development of this source of energy from the Earth's natural heat.

Program management has also slowed progress. The Department of Energy has not had a formal mechanism for setting priorities among projects. Both the Departments of Energy and the Interior have been slow in issuing regulations to accelerate the development and use of geothermal energy.

Some Federal actions have been taken to improve the program, but much remains to be done. This report makes several recommendations for further improvements.

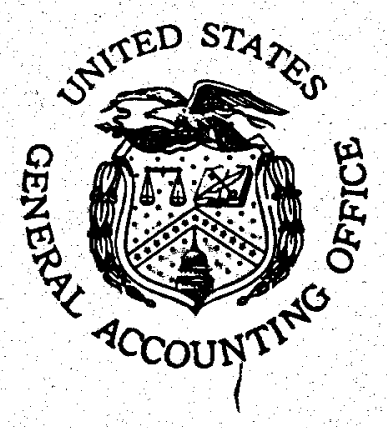




\section{DISCLAIMER}

This report was prepared as an account of work sponsored by an agency of the United States Government. Neither the United States Government nor any agency Thereof, nor any of their employees, makes any warranty, express or implied, or assumes any legal liability or responsibility for the accuracy, completeness, or usefulness of any information, apparatus, product, or process disclosed, or represents that its use would not infringe privately owned rights. Reference herein to any specific commercial product, process, or service by trade name, trademark, manufacturer, or otherwise does not necessarily constitute or imply its endorsement, recommendation, or favoring by the United States Government or any agency thereof. The views and opinions of authors expressed herein do not necessarily state or reflect those of the United States Government or any agency thereof. 


\section{DISCLAIMER}

Portions of this document may be illegible in electronic image products. Images are produced from the best available original document. 
COMPTROLLER GENERAL'S REPORT TO THE CONGRESS
GEOTHERMAL ENERGY: OBSTACLES AND UNCERTAINTIES IMPEDE ITS WIDESPREAD USE

\section{$\underline{D} \underline{\mathbf{G}} \underline{\mathrm{E}} \underline{\mathbf{S}} \underline{\mathrm{T}}$}

The Federal Government has been supporting efforts to accelerate the development and use of geothermal resources in the United states for some time. Although the Government has spent nearly $\$ 500 \mathrm{mill}$ ion over the past 5 years, development and use of these resources has proceeded slowly.

Theoretically, geothermal resources--the internal heat of the Earth--are a virtually inexhaustible energy source; however, only heat concentrations near the Earth's surface can be exploited for energy with today's technology.

The Department of Energy has the lead responsibility for the Federal geothermal program. The Department has tried to speed up the use of geothermal resources by stimulating private industry and local public power authorities to commercialize this energy for the production of electricity or direct heat.

Private industry's development efforts have focused primarily on high quality hydrothermal steam resources, such as those at the Geysers in California. Technology from the oil and gas industry has been adaptable and the economics clearly demonstrated in commercial applications. However, indus-. try has made only limited efforts to develop other geothermal resources, principally hightemperature, hot-water resources, such as those found in California's Imperial valley, due to high costs and financial and technical risks.

A number of widely varying obstacles and uncertainties make geothermal development costly and risky. These include

-lack of reliable detailed resource information: 
--lack of proven technology for defining, extracting, and using most of the recoverable resources for electric applications;

--complexities of administrative and regulatory requirements on development; and

--insufficient knowledge of possible environmental impacts and control technology.

These factors, coupled until recently with the abundance of more economically attractive energy alternatives resulted in the slow development of a domestic geothermal industry.

The Federal geothermal program has sought to resolve the obstacles and uncertainties. Al though some progress has been made, much work remains to be done. (See p. 13.)

The Department of Energy's lack of a formal management system for setting priorities among projects has often resulted in projects being undertaken which prove to be of limited or no value. The Department has been terminating some projects as a result of increased monitoring and evaluation efforts, but the project selection process has not significantly improved. (See p. 23.) To ensure that proposed projects are routinely and uniformly evaluated before they are undertaken, a formal mechanism for setting priorities among projects is needed. Such a mechanism would not only provide program managers with a better basis for selecting projects, but would ensure that all proposed projects were given adequate and equal consideration. (See p. 33.)

Delays in issuing implementing regulations have also hindered geothermal development and use. The Departments of Energy and the Interior have been slow in issuing regulations aimed at accelerating geothermal development and use. Some regulations have taken as long as 3 years to develop and issue. (See p. 26.)

As the geothermal development program evolves, legislative changes can be expected. GAO is concerned that it may be years before 
many of the benefits of legislation can be realized if agencies take as long to issue implementing regulations as they have in the past.

Each agency should place greater emphasis on issuing implementing regulations in a timely manner. In addition, the secretary of Energy, as Chairman of the Interagency Geothermal Coordinating Council, should systematically monitor each agency's progress to ensure that unnecessary delays are not encountered. (See p. 33.)

The National Energy Act of 1978 provided a number of incentives which should help stimulate geothermal development. However, some uncertainty remains concerning how much the incentives will do to promote more widespread use of these resources. (See p. 30.1

MATTERS FOR CONSIDERATION BY THE CONGRESS

Several bills have been introduced in the 96 th Congress which would amend the National Energy Act of 1978, the Geothermal Energy Research, Development, and Demonstration Act of 1974, and the Geothermal steam Act of 1970. These bills would provide additional Federal initiatives and incentives aimed at further accelerating geothermal energy's development and use.

In light of the current uncertainty surrounding the impact of the National Energy Act, before any such initiatives and incentives are enacted, the Department of Energy should make the Congress fully aware of the impact each could have on all phases of geothermal development and of the estimated annual costs. In this way, the congress could better determine which ones would best aid geothermal development and use.

In considering the magnitude or adeguacy of support for geothermal energy, the Congress should be mindful that many major obstacles and uncertainties are impeding its development and use, and that to some extent, slow 
development has been due to management problems.

Thus, in determining the appropriate level of Federal support, the Congress should recognize that much greater focus is needed on removing obstacles and uncertainties in order to realize geothermal's potential in the shortest possible time. (See p. 33.)

RECOMMENDATIONS TO THE

SECRETARY OF ENERGY

The Secretary of Energy should:

--Establish a formal mechanism for setting priorities among research, development, and demonstration projects to ensure that proposed projects are routinely and uniformly evaluated and that priority attention is given to projects aimed at resolving the major uncertainties and obstacles to widespread geothermal use in the shortest possible time frame.

--Place greater emphasis on the timely issuance of implementing regulations and, as Chairman of the Interagency Geothermal Coordinating Council, systematically monitor each agency's progress in developing regulations and adopt a strong leadership role in ensuring that regulations implementing changes to the geothermal program are developed and issued in a timely manner.

- At the time new Federal initiatives and incentives aimed at accelerating the development and use of geothermal energy are proposed, either by the administration or by the congress, determine the impact each could have on all phases of geothermal development and the estimated annual costs involved and submit each analysis to the appropriate congressional committees for their use during consideration of those initiatives and incentives. (See p. 34.) 
RECOMMENDATIONS TO THE

SECRETARY OF THE INTERIOR

The secretary of the Interior should:

--Follow up on the development of those regulations related to the leasing of Federal lands which were or have been in process for several years to identify and correct the problem and ensure that regulations are issued as soon as possible.

--Develop an internal system for monitoring the Department of the Interior's efforts to develop regulations relative to geothermal energy. The system should provide checkpoints that would alert the Secretary when such efforts are approaching 1 year in their development or are otherwise being delayed. (See p. 35.)

\section{AGENCY COMMENTS}

GAO obtained comments from the Department of Energy. (See app. I.) The Department basically agreed with the recommendations in the report. The Department's views and comments and GAO's evaluation are presented beginning on page 35. The Department of the Interior and the Enviromental protection Agency were each provided the opportunity to comment on a draft of this report. Their comments were not received in time to be considered in preparing the final report. 


\begin{tabular}{|c|c|c|}
\hline IGEST & 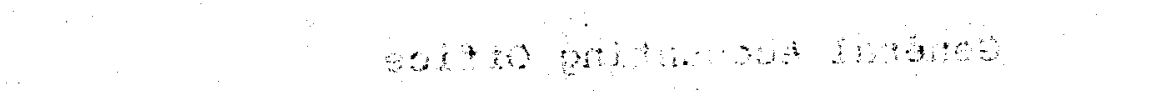 & CAD \\
\hline HAPTER & 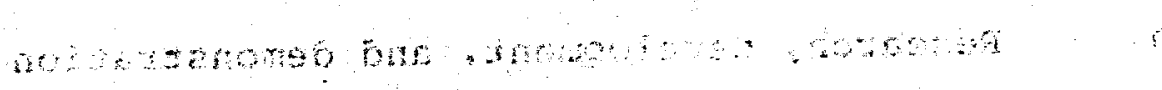 & \\
\hline 1 & $\begin{array}{l}\text { INTRODUCTION } \\
\text { Nature of geothermal energy } \\
\text { Federal role in developing geothermal } \\
\text { energy } \\
\text { Estimates of geothermal energy's } \\
\text { potential contribution have been } \\
\text { decreasing } \\
\text { scope of work }\end{array}$ & $\begin{array}{l}1 \\
1 \\
5\end{array}$ \\
\hline 2 & $\begin{array}{l}\text { OBSTACLES AND UNCERTAINTIES IMPEDING THE } \\
\text { WIDESPREAD USE OF GEOTHERMAL RESOURCES } \\
\text { Historical perspective on the use of } \\
\text { geothermal resources } \\
\text { Obstacles and uncertainties impeding } \\
\text { geothermal's greater use }\end{array}$ & 10 \\
\hline 3 & $\begin{array}{l}\text { ACTIONS NEEDED TO HELP ACCELERATE GEOTHERMAL } \\
\text { DEVELOPMENT } \\
\text { Need to improve project selection } \\
\text { Need to issue implementing regulations } \\
\text { in a timely manner } \\
\text { Recent legislation aimed at stimulating } \\
\text { geothermal's development and use }\end{array}$ & $\begin{array}{l}23 \\
23\end{array}$ \\
\hline 4 & $\begin{array}{l}\text { CONCLUSIONS, MATTERS FOR CONSIDERATION BY } \\
\text { THE CONGRESS, RECOMMENDATIONS, AGENCY } \\
\text { COMMENTS AND OUR EVALUATION } \\
\text { Conclusions } \\
\text { Matters for consideration by the } \\
\text { Congress } \\
\text { Recommendations to the secretary of } \\
\text { Energy } \\
\text { Recommendations to the secretary of } \\
\text { the Interior } \\
\text { Agency comments and our evaluation }\end{array}$ & $\begin{array}{l}32 \\
32 \\
33 \\
34 \\
35 \\
35\end{array}$ \\
\hline
\end{tabular}

APPENDIX

I Letter dated November 14, 1979, from the Department of Energy 
ABBREVIATIONS

DOE Department of Energy

ERDA Energy Research and Development Administration

GAO General Accounting office

$R D \& D \quad$ Research, development, and demonstration 


\section{CHAPTER 1}

\section{INTRODUCTION}

Geothermal resources are sources of natural heat in the Earth. Where concentrated near the Earth's surface, energy from these resources can be extracted to produce electricity or be used for direct heating. Although these resources have been used for many years in certain geographic areas, the Federal Government is seeking to further develop such resources and expand their use. Over the past 5 years, the Government has spent nearly half a billion dollars in support of geothermal energy development, but geothermal energy's development and use have proceeded slowly.

Much of this slowness is attributable to the economic, technical, institutional and environmental obstacles and uncertainties that have arisen as more has become known about developing geothermal resources. However, a contributing factor has been some problems in the Federal program. The purpose of this report is to make the Congress aware of the status of geothermal energy development and the obstacles, uncertainties, and other problems impeding geothermal energy's widespread use.

\section{NATURE OF GEOTHERMAL ENERGY}

The internal heat of the Earth is theoretically a virtually inexhaustible energy source; however, only heat concentrations near the Earth's surface can be exploited for energy with today's technology. However, if extractable; the earth's internal heat theoretically could help supply man's energy needs for eternity. Today's technology, however, allows us to reach only the heat contained in the upper portions of the Earth's crust. Most of this energy is so diffuse that it will never be economically recovered, but in some areas heat is concentrated into deposits which can be exploited. These deposits, usually classified as resource types, are (1) convective hydrothermal consisting of dry steam or hot water reservoirs; (2) geopressured reservoirs consisting of hot water, methane, and hydraulic pressure; (3) hot dry rock; (4) normal-gradient heat; and (5) magma, or molten rock.

\section{Hydr rothergmal resources}

In hydrothermal convection systems, most of the heat is transferred by the convective circulation of water or steam. Convection occurs in permeable rocks because of the buoyancy effect of heating (heated fluids tend to $r$ ise and denser cooler fluids tend to descend). Thus, convection tends to 
increase temperatures at higher levels at the expense of temperatures at lower levels and geothermal heat is transferred toward the surface. Most hydrothermal convection systems deliver a mixture of hot water and 10- to 30-percent steam at the well head. The fluids flash into steam as pressures decrease toward the surface.

In a few hydrothermal systems, such as the Geysers in California and Lardarello in Italy, wells produce saturated or even superheated steam, usually with no associated liquids. Pressures in these relatively rare systems appear to be controlled by vapor rather than by liquid, and thus the systems are called dry-steam or vapor-dominated systems. The steam from such systems can be piped directly through a turbine to produce electricity. This type of steam has been successfully used to produce electricity at today's market prices, but few dry steam reservoirs are known to exist.

Hot-water hydrothermal systems are dominated by circulating liquid, which transfers most of the heat and largely controls subsurface pressures. Some vapor may be present, usually occurring as bubbles dispersed in the hot waters of the shallower, low-pressure areas. Most of the known hot-water systems are characterized by hot springs that discharge at the surface. Some systems, however, are capped by impermeable rocks or exist where the local water table is below the ground level, and, thus, do not exhibit hot springs.

The temperatures of hot-water systems can be divided into three ranges; above 150 degrees Celsius (302 degrees Fahrenheit) for the possible generation of electricity; from 90 degrees to 150 degrees Celsius (194. to 302 degrees Fahrenheit) for possible space and process heating or perhaps for electricity; and below 90 degrees Celsius (194 degrees Fahrenheit) for possible direct heating only in specific locations. Hotwater systems currently provide space heating in some localities in the West, such as Boise, Idaho, and are being developed to produce electricity in California, New Mexico, Nevada, and Utah.

Hot-water hydrothermal resources are about 20 times as extensive as dry steam resources. Hydrothermal's use however is somewhat limited to the vicinity of the resource location because of the costs involved with long distance transmission of geothermal fluids. Potentially adverse environmental impacts is another factor which may limit the widespread use of these resources. 


\section{Geopressured resources}

Geopressured resources occur in regions where the normal heat flow of the Earth is trapped in insulating, impermeable clay beds in a subsiding basin. They are hotter than normallypressured formation fluids because the upward heat loss of the insulated water has been essentially stopped for millions of years. Heat continually $r$ ising from the Earth's interior is absorbed by the waters of these geopressured zones and water temperatures become much $h$ igher than is normal for the depth of their occurrence (up to 273 degrees Celsius or 523 degrees Fahrenheit). Another feature of these waters is that they are sometimes saturated with methane gas. This gas is recoverable. The Department of Energy (DOE) estimates 1 to 2 billion cubic feet of methane per year by 1985 , and 2 to 4 trillion cubic feet per year by 2000 , may be produced from geopressured waters. One trillion cubic feet of methane per year is equivalent to about 500,000 barrels of oil per day. Energy production projections, however, vary widely. Some oil companies, which have drilled in geopressured areas claim the reservoirs are not large enough to economically produce energy, while others believe the reservoirs are adequate in size.

Geopressured resources occur in wide belts both onshore and offshore under the gulf coast of Texas and Louisiana. The individual geopressured deposits are not continuous over the entire region, but they exist in blocks or reservoirs which are often partitioned by geological faults. Geologists believe these individual reservoirs are between 200 to 250 feet thick.

Although oil companies have been producing oil and natural gas from geopressured reservoirs for many years, geothermal energy in the form of heat, methane, or pressure, has not yet been extracted from these reservoirs. The reasons for this have been the relatively low price of gas, the uncertainty of recovery, and the high cost and risks of extracting the energy. Federal efforts are being directed toward producing commercial energy from the heat, methane, and/or pressure by 1985 .

Although DOE believes geopressured resources have the potential for making significant energy contributions in the mid- to long-term, it recognizes that many uncertainties or problems remain to be resolved before energy can be commercially produced. Among the problems which DOE recognizes as needing resolution are environmental, technical, and institutional; however, DOE acknowledges that the major problem currently needing resolution is the economic uncertainty of the geopressured reservoirs. DOE and industry officials agree much more information is needed on the capacity and 
characteristics of the reservoirs to ascertain if they contain sufficient quantities of heat, methane, and/or pressure for economic extraction.

\section{Hot dry rock resources}

Hot dry rock resources usually consist of dry impermeable. rocks covering a magma (molten rock) chamber at temperatures which increase with depth and proximity to the magma. since a great deal of heat seems to be stored in such rocks, if extraction of this heat becomes economically feasible, the Nation's geothermal potential will be greatly augmented. However, research efforts have not yet progressed to where the practical potential of exploiting hot dry rock resources can be determined. Hence, the hot dry rock resource base is very large and is found throughout the United states, but its value at present is only speculative. The major uncertainty at this time is whether technology can be developed to economically extract energy from hot dry rock deposits. DOE expects by 1985 to have sufficient data to base a decision regarding the commercial viability of the hot ary rock resource as an alternative energy source.

Normal-gradient heat resources

The normal-gradient heat resources are low- to moderatetemperature resources characteristic of the Eastern United states (radiogenic reservoirs). These resources could have potential for non-electric applications, however, efforts have only recently started to identify and quantify these geothermal gradients. DOE drilled over 5.0 deep temperature gradient wells along the East Coast in 1978-79 and completed one deep well test in 1979. DOE believes the results of these wells show promise for using these resources. According to DOE, however, more efforts are needed to provide a foundation for estimating the resource potential and for establishing commercialization plans.

\section{Magma resources}

With temperatures ranging from 600 to 1,500 degrees Celsius (1,112 to 2,732 degrees Fahrenheit), buried magma, or molten rock, resources represent large amounts of potentially high grade energy. The estimated annual energy potential of the U.S. magma resources is several hundred times the Nation's total annual energy consumption. Volcanoes, which may offer potential for recoverable magma energy, are located in Hawail, the Western United States, and Alaska. The available energy is immense, but technical and materials problems attendant with its use are formidable and, in many instances, very deep 
drilling will also be required. Direct tapping and use of the heat of magma, or molten rock, is a fascinating possibility, but DOE believes many years of study and development would be required before such a possibility could be brought to fruition.

\section{FEDERAL ROLE IN DEVELOPING}

\section{GEOTHERMĀ E ENERGY}

The Federal Government is supporting geothermal energy research, development, and demonstration (RD\&D) to accelerate the use of domestic geothermal resources by stimulating. private industry and $10 \mathrm{cal}$ power authorities to commercialize these resources for the production of electricity or for direct heat applications. The basic authorizing legislation are the Geothermal Research, Development, and Demonstration Act of 1974 (P.L. 93-410, Sept. 3, 1974); the Federal Nonnuclear Energy Research and Development Act of 1974 (P.L. 93-577, Dec. 31, 1974); and the Geothermal steam Act of 1970 (P.L. 91-581, Dec. 24, 1970). These acts authorize RD\&D on technological and socioeconomic problems concerning the development of geothermal energy and permit the leasing of Federal lands for geothermal development. The statutes also assigned the former Energy Research and Development Administration (ERDA) the lead responsibility for the Federal geothermal program. With the creation of DOE pursuant to the Department of Energy Organization Act (P. L. 95-91, Aug. 4, 1977), the lead responsibility has been transferred to DOE.

DOE works through the Interagency Geothermal Coordinating Council to encourage coordination within the Federal program. The Council is comprised of high level representatives from nine Federal agencies: the Departments of Energy, the Interior, Treasury, Agriculture, Commerce, Housing and urban Development, Defense; the Environmental Protection Agency; and the National Science Foundation. The council is chaired by DOE. The bulk of the Federal energy research and development is supported by DOE and the Department of the Inter lor, Federal support for geothermal development is expected to be about $\$ 161$ million in fiscal year 1980

DOE is currentiy giving priority attention to developing and promoting the use of those resources which have nearand mid-term potential. In this connection DOE's objectives, as set forth in its geothermal energy program plan, are to: (1) stimulate initial development of hydrothermal resources in the near-term (to 1985); (2) encourage their continued rapid growth in the mid-term (1985-2000) and beyond; (3) stimulate initial development of geopressured resources, including associated methane gas, by the early mid-term and to facilitate their continued growth; and (4) perform the advanced 
technological research and development reguired for the initial development of hot dry rock resources in the mid-term.

DOE's plans for accomplishing its objectives are principally concerned with developing economically viable and. environmentally acceptable technology to assist in making geothermal energy utilization competitive with available alternate energy resources in the near-and mid-terms. To help carry out its plans, DOE is supporting both technical and nontechnical activities. DOE's technical activities are aimed at: (1) reducing both the costs and uncertainties of geothermal reservoir exploration, assessment, development and utilization; (2) developing and demonstrating the most costeffective heat exchange and energy conversion technologies; and (3) developing and demonstrating technology for acceptable control of environmental impacts. Nontechnical program activities are aimed at: (1) reducing institutional barriers, such as tax and legal uncertainties; (2) streamlining leasing, regulatory, and permit granting procedures; (3) providing appropriate incentives and ensuring equal competition with respect to alternate energy technologies; and (4) disseminating information thereby gaining public acceptance of the commercial use of geothermal energy.

The Department of the Interior's geothermal efforts are primarily managed by the U.S. Geological Survey and the Bureau of Land Management. The goal of the U.S. Geological Survey's geothermal research program is to understand the nature, distribution, and energy potential of the Nation's geothermal resources. The knowledge gained from the research activities of the program is used to provide documented estimates of the magnitude of these resources for use in energy planning. In addition, the program seeks to advance the technology and methodology of exploring for geothermal energy sources, develop a detailed knowledge of geothermal systems, and apply geoscience procedures to problems associated with geothermal development. The Bureau of Land Management is responsible for the leasing of federally-owned geothermal resources. Lands eligible for geothermal leasing include certain lands administered by the Secretary of the Interior; lands administered by the Department of Agriculture through the Forest Service; and lands which the United States has transferred surface-title, but reserved the right to geothermal resources.

Certain lands administered by the Department of the Inte$r$ ior, however, are not available for geothermal leasing or development. These include lands administered by the National Park service; lands within national recreation areas, $f$ ish hatcheries, game ranges, wildlife ranges, and water-fowl protection areas; lands reserved for protection and conservation of wildlife species threatened with extinction; tribally or 
individually-owned Indian trust or restricted lands; and lands which may be temporarily withdrawn from certain or all users pending classification.

other Federal agencies involved in geothermal resources devêlopment have more limited, but yet important róles. For example, the El ironmental protection Agency ls concerned with the environmental impacts and the Forest service may allow its lands to be leased for geothermal exploration or use.

Federal geothermal funding support has progressively increased in recent years. For fiscal year 1979 , combined Federal funding for geothermal activities was about $\$ 180.9 \mathrm{mil-}$ lion, but it is expected to decline to $\$ 161.5$ mililon in fiscal year 1980. The following table shows the Federal funding for geothermal activities.

Federal geothermal funding by fiscal year

1975 (note a) $1977 \quad 1978 \quad 1979$ (est.)

DOE (note b) $\$ 28.1 \quad \$ 43.3 \quad \$ 57.2 \quad \$ 110.3 \quad \$ 160.1 \quad \$ 143.0$

other agencies

(note c)

$\begin{array}{llllllllll}20.4 & 20.0 & 17.3 & 18.8 & 20.8 & 18.5\end{array}$

Total

$\$ 48.5 \$ 63.3 \quad \$ 74.5 \quad \$ 129.1 \$ 180.9 \$ 161.5$

a/Includes transition quarter during changeover to a new fiscal year.

b/Includes the former ERDA funding for fiscal years $1975-77$.

c/Primarily funding provided by the U.S. Geological Survey

(13.4 milition for FY 1980) and the Bureau of Land Management

$(\$ 2.6$ million for FYे 1980$)$.

ESTIMATES OF GEOTHERMAL

ENERGY'S POTENTIAL CONTRIBUTION

HAVE BEEN DECREASING

Although the Federal Government has spent nearly $\$ 500 \mathrm{mil}-$ 110 over the past 5 years to accelerate the development of geothermal energy, the estimated near-and mid-term perception of geothermal's contribution has become less optimistic. Although some variations in estimating geothermal energy potentials arise because of diferent methodologies and assumptions used in making the estimates the trend of the amount estimated 
indicate that geothermal energy will not be developed as early as initially expected.

Listed below are the source of some of these estimates, the year they were made, and the amount of estimated megawatts of potential electricity.

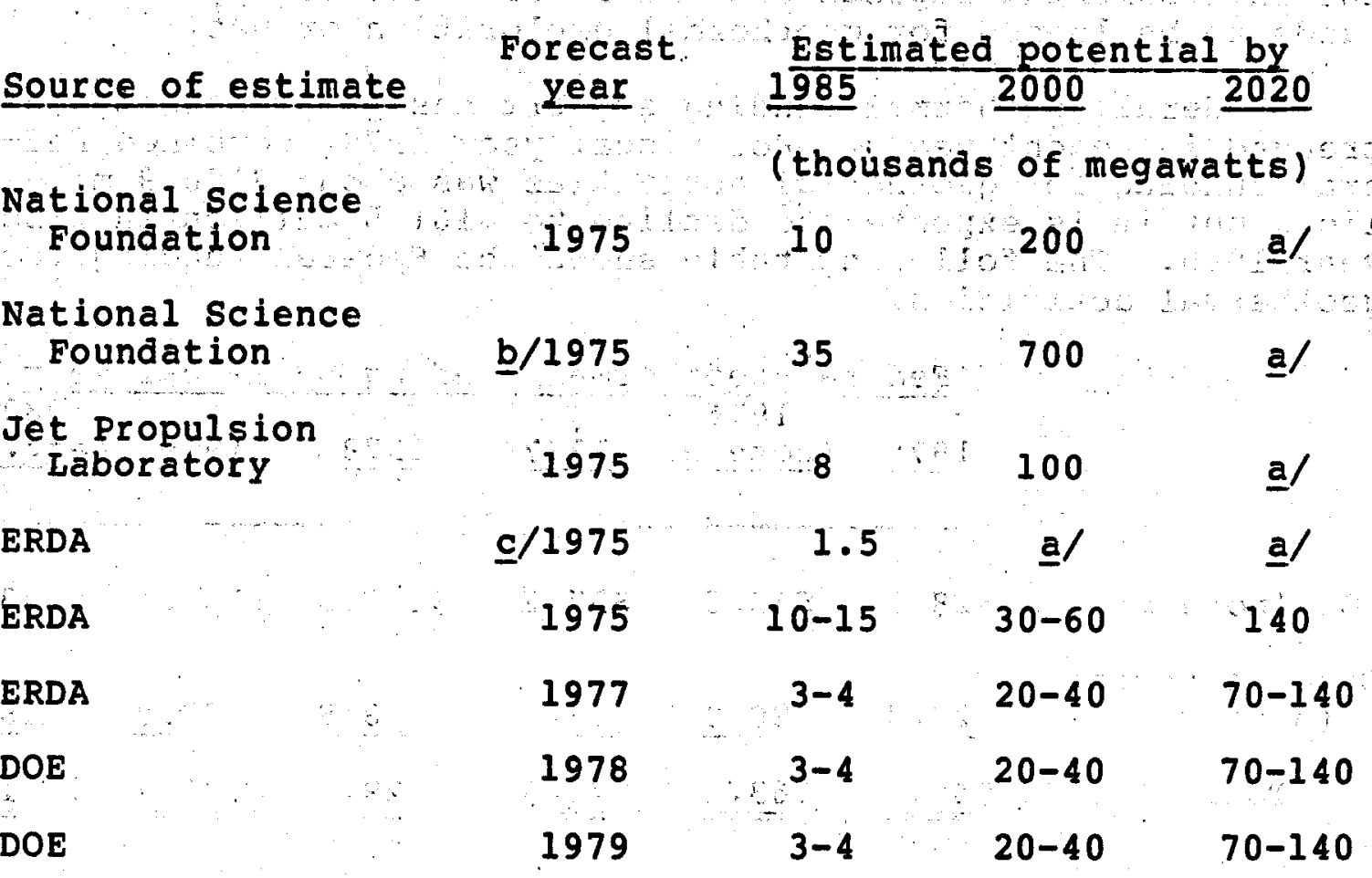

a/No estimate made.

b/Estimate assumed that crash Governmént program would be undertaken.

c/Estimate assumed a Federal program would not be undertaken.

- While the earlier studies were overly optimistic concerning geothermal's realistic contribution, the most recent estimates may also be somewhat optimistic. For example, geothermal developers have questioned the estimated 3,000 to 4,000 megawatts by 1985. Many felt that this estimate was unreasonable because among other things, enough geothermal resources had not been identified to support the estimate. Similarly, a DOE program official told us that it is unlikely the 3,000 megawatts will be obtained by 1985 . He explained that the estimate provided an "optimistic basis" for framing measures needed to bring about an increased use of geothermal energy. This viewpoint was also supported in a March 1979 report of the Interagency Geothermal Coordinating Council. In that report 
the Council also cautioned that the estimate did not consider the relative cost of geothermal versus other energy forms, nor the potential impact of changing environmental regulations, both of which could effect geothermal's actual contribution. In adejtion, to obtain geothermal energy by 1985 , geothermal development projects would already have to be initiated. From our review of projects initiated to date, it appears that these projects could produce about 2,000 megawatts from geothermal resources by 1985 .

DOE officials, in commenting on this report, stated that prospects appear favorable for the achievement of 3,000 megawatts of electric generating capacity from geothermal resoutces by 1985 based on (1) projects initiated to date, (2) developers intentions to proceed with planned projects, and (3) recent utility and DOE studies projecting geothermal development. We believe that these may be somewhat optimistic projections. This is evidenced in the fact that these projections now include about 1,900 megawatts by 1985 from the dry steam reservoirs in the Geysers, the only producing field in the United States. This is a decrease from the March 1979 projection of about 2,100 megawatts made by the Interagency Geothermal Coordinating Council and DOE. In addition, one official involved with developing the Geysers told us that the 1,900 megawatts by 1985 is very optimistlc based on past $h$ istories of delays. He added that some powerplants included in this projection are still unsited and when they will come on line is uncertain. Another official involved with the Geysers development believes that the Geysers will reach only 1,600 megawatts by 1990 due to permitting delays being experienced. Therefore, we believe that there remains considerable uncertainty about the amount of geothermal electric generating, capacity that will be produced by 1985 .

\section{SCOPE OF WORK}

We made our review principally at DoE, U.S. Geological Survey, and the Bureau of Land Management headquarters in Washington, D.C., and at their various field offices around the country. We also visited several state offices and major geothermal resource sites and observed Federal and private projects. We analyzed the leglislative history associated with geothermal development and the Federal geothermal program efforts and examined Federal, State, and privately financed geothermal studies. We interviewed Federal and state officials involved in geothermal development, analyzed documents they provided, and discussed geothermal development with private industry representatives. 


\section{CHAPTER 2}

\section{OBSTACLES AND UNCERTAINTIES}

\section{IMPEDING TEE WIDESPREAD USE OF}

\section{GEOTHERMAL RESOURCES}

Geothermal resources in various locations throughout the world, including the United states, are being used for energy, but in relatively small amounts. This is largely because energy could be economically extracted only from those relatively few geothermal resources with favorable charactertistics. The 1973-74 Arab oil embargo brought renewed awareness and interest in geothermal energy for both electric and non-electric uses. In the United states, the federal Government has been supporting efforts to accelerate the development and use of such resources. However, to develop these resources to the point where they may have more widespread use, many obstacles and uncertainties have to be addressed.

HISTORICAL PERSPECTIVE ON THE USE OF GEOTHERMAL RESOURCES

Geothermal resources throughout the world have been used for various purposes since ancient times. However, useful applications have depended largely on the accessibility, composition, temperature, and pressures of the resources used.

Hot springs, where underground geothermal water flows naturally to the surface, have been known and used since ancient times. Such springs were used as "medicinal" spas in ancient Greece, Rome, Babylonia, and Japan. The Romans established hot mineral bath spas throughout the empire reaching as far north as Bath. England. In 1867, the Hungarians sank a well to secure natural mineral waters, and by early 1900 the drilling of hot water wells to augment natural hot springs was common in Italy, Germany, and Iceland. Hot springs are still popular resorts throughout the world, including those in the United States.

In 1904 at Lardarel10, Italy, electricity was first produced from ary steam hydrothermal resources. Although the first generator only produced enough energy for about five lightbulbs, since 1913 Lardarello's dry steam fields have been producing almost continuous electricity and currently have a generating capacity of 380 megawatts.

In the 1930s, Iceland pioneered using geothermal fluids for household and commercial heating purposes. An elaborate network of pipes and conduits carries hot water from more than 
100 geothermal wells in the vicinity of Iceland's capital, Reykjavik, to 90 percent of its homes. The deepest well is about 7,000 feet and the temperatures of the hydrothermal reservoirs range from about 100 to 150 degrees Celsius ( 212 to 302 degrees Fahrenheit). The hot water is carried for distances up to 10 miles and is delivered at about 80 degrees Celsius ( 175 degrees Fahrenheit). In addition to heating homes, the hot water is widely used in Iceland for heating baths, swimming pools, and greenhouses. Iceland's success in using geothermal resources is partly due to a remarkably low mineral content of its hydrothermal waters.

Japan extensively explored geothermal resources for use in a variety of direct heating applications over the last half century. The first geothermal heating of greenhouses began in the early 1920s, and this technigue is still widely used today to produce many kinds of vegetables and tropical fruits. Japan began producing small amounts of electricity from hot water resources in 1924 and currently produces about .170 megawatts of electricity from such resources. Japan has thousands of natural hot mineral water resorts, baths and therapeutic spas, and probably leads the world in the use of geothermal resources for these purposes. Industrial applications of geothermal resources include sulfur recovery, commercial baking, salt recovery from seawater, and experimental fish farming.

The Soviet Union has developed geothermal heating systems over a wide geographical area. At several locations, centralized municipal geothermal heating installations furnish hot water and heat houses for communities of 15,000 to 18,000 people. Geothermal energy is also used in the Soviet Union in an oil refinery and as a heat source for greenhouses, seedbeds, and baths.

In Bungary, geothermal reservoirs have been widely used for space heating applications. For example, some 1,200 housing units and associated municipal and commercial buildings are heated by hot geothermal water in the city of szeged at costs well below those of conventional Euels. Geothermal heat is also used in Hungary for agricultural purposes, such as heating greenhouses, farm buildings, and drying crops.

New Zealand is another country which uses direct geothermal heating for several different applications. Natural steam from geothermal wells is used to heat pure water for the generation of high guality steam, which is used directly in a number of industrial mill processes. This steam is also used to operate log-handling equipment, dry timber, and to generate electricity. In the New Zealand city of Rotorua, which has a population of 30,000 , more than a thousand hot water wells 
supply heat to commercial establishments, houses, schools, hospitals, and hotels. Additional direct heating applications for geothermal energy in New zealand are in agriculture.

Mexico has been producing electricity from hydrothermal resources since 1973. Mexico's largest geothermal electrical power development is a 150 megawatt plant at the Cerro Prieto field, just below the California border. This plant has been in operation since 1973 and lies at the south end of the geothermal zone overlain by the Imperial Valley and the salton Sea of California. Cerro Prieto is considered important to the United States for what it may reveal about an essentially shared resource.

In the United States, geothermal space heating has been successfully carried out for a number of years in southern Idaho and oregon. Since the 1890s, the City of Boise, Idaho has used geothermal resources for space heating some homes and businesses. At Klamath Falls, oregon, geothermal hot water is used, either directly or through heat exchange systems, to heat buildings. Geothermal hot water is also used in oregon and Idaho for greenhouses, baths, farm buildings, schools, and resorts. Some towns and farms in California and other western states have recently undertaken similar projects. The nonelectrical use of hot water geothermal resources in this country is estimated to be equivalent to about 15-20 megawatts of electricity. DOE is supporting about 20 non-electric development projects that, according to DOE, (1) accounts for most of the non-electric development underway and (2) should result in a tenfold increase in non-electric use by 1982 , with further growth before 1985 .

In 1960, utilities and private industry developers began generating electricity from the hydrothermal dry steam fields called the Geysers in northern California. Initial production was about 12 megawatts of electricity. By 1979, production from this field stood at 665 megawatts with current plans calling for another 1,900 megawatts by the 1985-2000 time frame. More electricity is produced from the Geysers than from any other geothermal development in the world.

Many other countries have used direct geothermal heat successfully and economically, but such applications are limited to the immediate geographic regions of the wells. To have more flexibility in the use of geothermal resources, many countries are exploring ways to generate electricity. However, at present this has been practical with only a relatively few geothermal reservoirs. Other countries which are exploring the use of geothermal resources or have development projects underway include: Chile, China, El Salvador, Ethiopia, Guadeloupe, Indonesia, Kenya, Nicaragua, Philippines, Taiwan, Turkey, and 
Zaire. Another 30 countries have begun to gather data or otherwise 'show interest.

A recent Brown University study showed that in 1978,10 countries throughout the world had a total of 1,658 megawatts of electrical capacity from hydrothermal resources, as shown in the following table.

World Electrical Generation Capacity In 1978 From Geothermal Resources (Megawatts)

Country

United states (note a)

Italy

New Zealand

Phil ippines

Japan

Mexico

Iceland

El Salvador

Soviet Union

Turkey

Total
Installed capacity

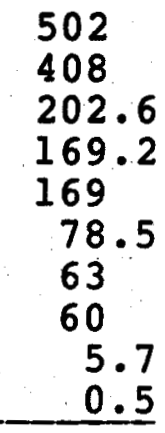

$\underline{1,658.5}$

a/Development at Geysers, California.

Since the study was published, the United states capacity has increased to 665 megawatts and Mexico's to 153; and Nicaragua also brought 30 megawatts on 1 ine. This would bring current world electrical generation capacity to about 1,926 megawatts.

OBSTACLES AND UNCERTAINTIES

IMPEDING GEOTHERMAL'S

GREATER USE

Following the 1973-74 Arab oil embargo, the United States became increasingly aware of and interested in the development of geothermal resources. Although geothermal resources had been used in various locations throughout the world, such uses had been limited to regions near geothermal wells and from a relatively few reservoirs.

Private industry's development of geothermal resources has primarily focused on the high quality hydrothermal steam resources, such as those at the Geysers. The technology from the oil and gas industry has been adaptable and the economics clearly demonstrated in commercial applications. However, industry made only limited efforts to develop other 
geothermal resources, principally higher temperature hot water hydrothermal resources such as those found in Californta's Imperlal Valley, due to the high costs and financial and technical risks associated with such development.

The high costs and risks of developing geothermal energy resources resulted from number of obstacles and uncertainties of a widely varying nature, including

--lack of reliable detalled resource information;

--lack of proven technology for defining, extracting, and using most of the recoverable resources for electric applications;

--complexities of administrative and regulatory requirements on geothermal development; and

--insufficient knowledge of possible environmental impacts and control technology.

These factors coupled, until recently, with the availability of more economically attractive energy alternatives, resulted in the slow development of a domestic geothermal industry.

Federal geothermal program efforts have sought to resolve these obstacles and uncertainties. In addition, new administrative procedures and mechanisms for coordinating Federal RD\&D efforts had to be established. Although some progress has been made toward resolving the obstacles and uncertainties, much work remains to be done. The major obstacles and uncertainties faced by the Federal geothermal RD\&D program are discussed below.

Resource assessment and exploration

Although the United states is known to have an abundance of geothermal resources, many uncertainties remain as to the nature and potential of these resources. To help reduce such uncertainties, resource areas are being assessed and explored. Geothermal resource assessments are conducted to estimate the amount of thermal energy that might be extracted and used economically at some reasonable future time. A resource assessment may be regional or national in scope and thus provides a framework for long-term energy policy and strategy decisions by industry and Government. Such assessments are not intended to establish specific reserve figures for short-term investment and marketing decisions but to give an overall perspective at a particular time. Areas assessed to have large resource potential are explored for additional information on 
the characteristics of the geothermal reservoirs within those areas.

The first systematic effort to estimate the geothermal resources of the entire United states was published in 1975 as U.S. Geological Survey Circular 726, "Assessment of Geothermal Resources of the United states--1975." This study used the data available in early 1975 to estimate the quantities of geothermal energy available. Using more and recent data from exploration technology development, and direct utilization, the Geological survey reevaluated the geothermal resources of the United States in the 1 ight of data available in June 1978. This new geothermal resource assessment was published in the February 1979, Circular 790, "Assessment of Geothermal Resources of the United States--1978."

The 1978 assessment is essentially a refinement of the 1975 assessment, but includes the description of areas favorable for the discovery and development of low temperature (less than 90 degrees Celsius or 194 degrees Fahrenheit) geothermal waters from depths less than one kilometer, and the assessment of geopressured resources is expanded to include a more detailed inventory of these resources. The 1978 assessment shows a decrease in the number of identified hydrothermal systems; a decrease in the size of several of the largest systems inventoried in 1975; and a greater preponderance of intermediate temperature systems ( 90 to 150 degrees Celsius or 194 to 302 degrees Fahrenheit) over high temperature systems (above 150 degrees Celsius or 302 degrees Fahrenheit... Systems above 150 degrees Celsius, or 302 degrees Fahrenheit are considered necessary for electrical conversion. The assessment also concludes that, given present knowledge and the state of technology, the resource base for energy that might be extractable by proposed hot dry rock energy technology cannot be determined, nor the amount of energy extractable from geopressued resources be estimated with any certainty.

Exploration activities help confirm the potential esti-: mated by resource assessments and provide better information for use in selecting sites for geothermal development projects. Industry and Government-sponsored drilling since early 1975 has confirmed many of the estimates made in the 1975 resource assessment and helped provide better information for the 1978 assessment. Results of exploratory activities have also helped in selecting sites for additional tests of geothermal reservoirs.

As evidenced by the 1978 assessment, progress has been made in resource assessment and exploration. As a result, the U.S. Geological Survey is reducing its assessment efforts. Such efforts are being reduced because Geological 
Survey officials believe that the 1978 resource assessment has sufficiently identified geothermal resources which can be, but have not been developed.

Much more progress, however, will have to be made before industry will pursue widespread exploration. Currently, exploration activities are carried out by drilling exploratory wells. Only about one in 15 , or about 6 percent, of the exploratory wells have resulted in discoveries of promising and potentialiy productive hot water reservoirs. The cost of drilling geothermal wells ranges from $\$ 400,000$ to $\$ 1$ million, depending on rock types encountered and depth requirements.

Some unusual problems are encountered in geothermal well drilling. The strata generally consist of hard, abrasive, fractured rock that causes a substantial shortening of the usual life of drill bits. This results in unintentionally deviated holes that wear the drill pipe rapidly. Additionally, the heat and brine in geothermal zones lead to metal fatique and corrosion problems as well as problems with seals, lubricants, and other materials. Hence, geothermal drilling requires improved drilling equipment and techniques, improved downhole drilling motors, a greater understanding of rock mechanics, and improved seals, lubricants, and other materials.

\section{Technology development}

Current geothermal energy drilling technology has been largely adapted from the oil industry, but is often not well suited to the different geologic environment of geothermal resources (high temperature, hard abrasive rock, corrosive chemicals in brine). With existing technology, high cost and high technical and economic $r$ isks hamper geothermal energy development, especially electric development. Hence, ERDA and now DOE have focused their geothermal technology development work on reducing costs of resource assessment and exploration; reducing capital costs of electricity generating facilities; improving energy extraction and conversion technology: and reducing, the technical risks of producing, using, and disposing of geothermal fluids.

Efforts to date have resulted in some cost reducing technology, but work has not yet progressed to sufficiently reduce the costs and $r$ isks involved to induce significant amounts of private investment. Efforts underway are aimed at improving components enough to reduce geothermal drilling costs 25 percent and developing advanced drilling systems that would reduce drilling costs by 50 percent, improving well productivity by increasing flow rates, reducing the number of costly wells needed, and developing materials capable 
of withstanding high temperatures. While these efforts are directed toward reducing assessment and exploration costs, geothermal drilling costs have significantly increased in the past 4 years from a range of $\$ 300,000$ to" $\$ 600,000$ per well, to $\$ 400,000$ to $\$ 1$ million per well.

Efforts are also directed at reducing geothermal electric generating costs by developing advanced energy conversion systems for the more predominant moderate temperature geothermal resources which are more expensive to develop than the high temperature resources. Improved conversion technology at lower costs may help accelerate making moderate temperature resources commericial. Some other methods, devices, and materials being developed also show promise of reducing costs and risks in the near-and mid-terms. Efforts are also directed at developing an extraction technology for the hot dry rock resource. However, until new technologies are successfully demonstrated, industry or other developers and investors are unilikely to undertake projects which depend on the successful use of those research and development results.

Institutional development

To establish an expanded geothermal energy industry, institutional support is needed because the requisite investor interest and industrial capability do not exist. Uncertainties about the actual power production costs and reservoir lifetimes associated with untried geothermal sites, as-well as the basic uncertainties of a new technology, have discouraged most utilities from proceeding with geothermal energy development. The few utilities that have taken an interest have had 1 ittle success in attracting support from public utility commissions, lenders, or investors.

Thus, the Federal Government has been trying to stimulate the forming of a consortium of institutions needed to commercialize geothermal resources; i.e., utilities, investors, resource development companies and specialized equipment manufacturers: Efforts made to date involve making loan guarantees $p$ conducting economic studies, leasing public lands, costsharing with industry for demonstration projects, funding of industry-built pilot or prototype plants, and streamlining administrative procedures for leasing and for preparing environmental assessments and impact statements. Although private geothermal development and use have proceeded slowly, DOE officials point out that much progress has been made toward establishing the reguisite framework for developing geothermal resources. 
Environmental assessment

In addition to forming the required institutional consortium to successfully place new geothermal energy technologies in the marketplace, environmental concerns and probiems must be integrated and carried out in parallel with the development of the associated technologies to ensure that environmental concerns are identified and addressed prior to making major commitments to the development and/or commercialization of such technologies.

When the Federal geothermal RD\&D program began in 1975, major environmental uncertainties existed. Most of the electric and non-electric geothermal installations in the United States were, however, designed and built prior to the establishment of U.S. environmental standards. Without modification, many of these installations would not meet the current applicable standards. Although liquid-dominated geothermal energy facilities were operating in foreign countries, they similarly were not designed to be compatible with, and do not meet, U.S. environmental standards. Hence, functional and economical equipment and methods for geothermal energy use that would comply with environmental standards had not been developed.

Environmental activities have been actively pursued in various Federal agencies, particularly by DOE and the Environmental Protection Agency, and private industry. To date various Government studies have identified nine major environmental concerns which could possibly arise in connection with the development and use of geothermal resources:

--Emission of compounds or chemicals, such as hydrogen sulfide, carbon dioxide, radon, mercury and boron into the atomsphere which may impact on local environments and human health.

- Contamination of water supplies resulting from surface or underground releases of large volumes of spent geothermal fluids.

- Noise pollution associated with exploration and drilling, well venting, and operational processes which, if uncontrolled, may have adverse effects on animals and human health.

- Collapse or gradual subsidence of the land surface resulting from the removal of large quantities of underground fluids. 
--Increased frequency or magnitude of earthquakes resulting from the withdrawal or injection of fluids.

--Conflicts over the most beneficial uses of water because many proposed methods of using geothermal energy reguire additional sources of water.

- Conflicts with other land uses such as for wildilfe, agriculture, or recreation.

- Local opposition because geothermal resource development will Increase the demand for workers and provide an influx of money which may affect social mores and and life styles.

- Safety and occupational health problems which may arise if high pressure, corrosive geothermal fluids and explosive fluids, such as isobutane and propane, are not properly handled.

These and possibly other yet to be identified concerns, if shown to be adverse, will have to be resolved, mitigated, or accepted as tradeoff for energy production before geothermal resources can have widespread commercial use.

DOE believes that each geothermal project would not encounter all of the potential concerns listed and that these known major environmental concerns can be controlled to levels with impacts that are minor in comparison to impacts of other energy developments. One DOE study estimates that it will take up to 8-10 years of research to resolve or at least partly resolve the known major concerns.

However, in the meantime these environmental concerns can delay geothermal development. For example, one of the above concerns has fust recently surfaced as an obstacle to a planned project. New Mexico's hydrogen sulfide emissions standard is threatening the planned development of DOE's first geothermal demonstration plant. In August 1979, DOE signed a contract with the Public service Company of New Mexico and the Union Oil Company to build a $\$ 124.6$ million, 50 megawatt geothermal demonstration plant in New Mexico. However, the Public Service Company of New Mexico recently told the State's Environmental Improvement Board that the plant will not be built unless New Mexico's hydrogen sulfide emissions standard is modified. State hearings are scheduled to address this matter. The Public service Company of New Mexico, however, has stated that, until a solution or compromise to this obstacle is arrived at, there will not be any geothermal development in that state. 
The release of hydrogen sulfide is also a substantial problem at the Geysers and has resulted in adverse reactions from the downwind communities. Public concern over the odors from existing geothermal plants was a prime element in the Nation's decision to delay permits for construction of powerplants between 1972 and 1976 , and may threaten the renewal of permits for the older operating plants. A new process that may control about 90 percent of the hydrogen sulfide emissions is now being used on the new powerplants at the Geysers. To control the hydrogen sulfide emissions from the older powerplants, new methods are under development to remove the hydrogen sulfide before it reaches the turbines of these plants.

Program management and coordination

To implement the geothermal RD\&D program, many new administrative procedures had to be developed and implemented. For example, procedures had to be established for leasing Federal lands, making loan guarantees, and conducting environmental assessments. Developing and implementing many such procedures was made more difficult because concurrent with the development of such procedures, new agency administrative procedures had to be developed and mechanisms for coordinating Federal geothermal RD\&D efforts established.

Concurrent with establishing a Federal geothermal RD\&D program to help consolidate Federal energy RD\&D activities, the Congress created a new agency--the Energy Research and Development Administration. In January 1975, ERDA came into existence and was charged with bringing together energy RD\&D programs formerly carried out by the Department of the Interior, the former Atomic Energy Commission, the National Science Foundation, and the Environmental Protection Agency. A number of organizational components of other Government entities were transferred essentially intact to ERDA. These organizational components brought with them a considerable amount of expertise and talent, but also a variety of management practices.

Thus, ERDA was faced with establishing uniform management procedures to enable administrative paperwork to flow smoothly and efficiently. During most of its nearly 3 years of existence, ERDA made extensive efforts toward developing a program planning, budgeting, and review system, which was designed to provide an overall framework for planning and budgeting and to streamline the administrative procedures. However, in the absence of the system's implementation, systematic planning and budgeting were not attained and paperwork processing was often delayed. This contributed to the delay of geothermal energy's programmatic progress. 
Congressionally mandated efforts specifically applicable to the development of geothermal energy were being pursued in at least five other agencies. As statutory lead agency, ERDA was made responsible for encouraging and coordinating the development or adoption of appropriate programs or policies by the other agencies. With the establishment of DOE in 1977, these responsibilities were transferred to DOE.

Interaction of all involved agencies remains an important element of the Federal geothermal RD\&D program. The U.S. Geological Survey's national and regional resource exploration and assessment programs, and its environmental programs, directly complement DOE's related site-specific programs. The leasing policies and programs of the Bureau of Land Management, the Forest Service, and the Bureau of Indian Affairs must also be coordinated as essential parts of the Federal commercialization strategy, because more than half of the estimated potential hydrothermal resources are on Federal lands. The participation of regulatory agencies, such as the Environmental Protection Agency, is also crucial to timely commercialization.

ERDA and DOE have employed the Interagency Geothermal Coordinating Council as the principal mechanism for coordinating the Federal geothermal RD\&D effort. The Council has established working groups and panels for discussing Federal incentives and barriers affecting the respective geothermal development efforts of the member agencies. For example, the Council's Budget Planning and Working Group has held meetings to bring member agencies up to date on each other's activities and lay the groundwork for coordinating and implementing their respective plans. Also, in support of the Budget and Planning Working Group, DOE and the Department of the Interior are developing a computerized program management system to facilitate the monitoring of geothermal energy development progress in the private sector.

The President, in his April 1977 energy message, directed the Departments of the Interior and Agriculture to streamline their procedures for leasing and environmental reviews "to remove unnecessary barriers to development of geothermal resources." In response to this direction, an Interagency Geothermal streamlining Task Force was formed under the council.

Since its inception, the streamlining Task Force has conducted an indepth study of Federal leasing and permit procedures and has held a series of public meetings to solicit suggestions and comments. Several special studies of development of geothermal resources on Federal lands were also accomplished under contract in support of the Task Force's 
work. The Task Force report to the Council included 19 specific legislative, regulatory, and administrative recommendations expected to improve Federal geothermal leasing procedures. Sixteen (16) of the 19 recommendations were approved by the Council in January 1979, while the remaining 3 were remanded for further study. In our report entitled "How to Speed Development of Geothermal Energy on Federal Lands" (EMD-80-13, Oct. 26, 1979) we stated that we generally support the Task Force recommendations as well as legislation currently being considered that is patterned after the recommendations.

While these and a number of other efforts are being made to improve interagency coordination, coordinated planning is of an evolving nature and continued aggressive efforts are needed.

DOE officials point out that there has been a substantial amount of development activity that will lead to geothermal use. Because of the long leadtime required for development, these activities have not yet produced power-on-line, although they do represent activities aimed at producing energy by 1985. DOE officials also point out that several major industrial development projects are underway which should lead to electric powerplants in California, Utah, Nevada, and New Mexico by 1984 and that some of these projects have been accelerated through DOE's cost-shared drilling program, loan guarantees, demonstration program, and technology development. 


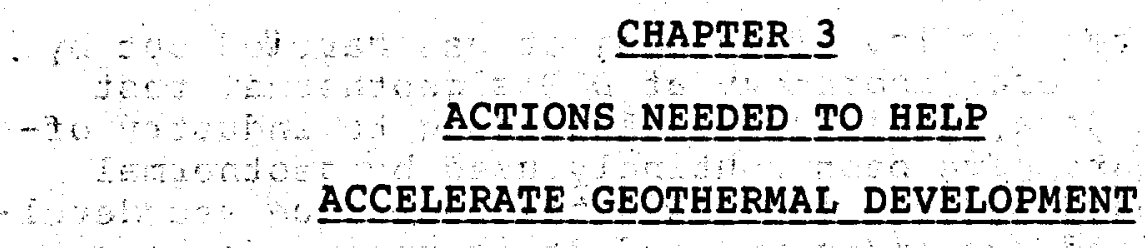

Al though much of geothermal energy's slow development can be attributed to obstacles and uncertainties, some of this slowness has resulted from problems in managing the program. DOE has taken some actions to improve the program, but additional actions are needed. In addition, some legislative actions have been taken to help accelerate the program, but in light of the obstacles and uncertainties impeding the widespread use of geothermal resources, the ultimate impact such actions will have on promoting geothermal's use is a relative unknown.

\section{NEED TO IMPROVE PROJECT}

\section{SELECTION}

In an effort to get geothermal research and development efforts underway as soon as possible, projects were often undertaken which ultimately have proven to be of limited or no value, The cause of the problem appears to have been the lack of a formal management system to ensure that projects are undertaken, monitored, and evaluated on the bas is of uniform criteria which are consistent with program goals. DOE has recently improved its monitoring and evaluation of ongoing projects and has been terminating those projects which show little or no potential to help achieve program goals. However uniform criteria for setting priorities among projects to be undertaken have not been established. Nor does the program office have an adequate mechanism for providing current data on projects in various stages of review and approval. Projects are selected to be undertaken by program managers largely using their individual criteria and undocumented technical judgments.

During our review, industry officials often told us that they questioned the value of geothermal development projects sponsored by DOE. They told us that al though some DOEsponsored projects are outstanding and helpful to them, much of the work undertaken merely duplicates information or technology already known to those actiye in geothermal development and that many projects are designed to "reinvent the wheel." In general, they believed projects should be selected in a more discriminating manner so that geothermal energy's problems are more clearly addressed.

An example of one project cited as being duplicative was a project designed to "pioneer" pressure-sensed interference 
tests for geothermal wells. This project was carried out by . the Lawrence Livermore Laboratory at DoE's geothermal test facility in East Mesa, California. According to industry officials, such tests have been routinely used by geothermal developers for many years. They said the technique was developed by the oil and gas industry, and it is useful for geothermal wells and is already commercially available.

Another project cited was for determining the optimum placement of production and reinjection wells in a geothermal resource field. Industry officials told us that the model used standard industrial techniques and that the approach to the problems was naive and far behind industry practice one official commented, "they (DOE) are playing at games without either the know-how or the technical capabilities of the private-sector."

still another project was one which tested two techniques for probing geothermal resources. According to DOE, these tests demonstrated the use of the "P"-wave and "S"-wave vibroseis techniques for the apparent ability to detect high fluid contents and to refine the structural detafl of geothermal resources. Industry officials, however, told us that the " $P$ "-wave technique is already in commercial use and does not need any Government funding to establish its merits. They said that the "S"-wave technique is experimental, but believe it to be of little or no use.

In commenting on the sponsoring of projects which demonstrate known techniques or provide known information, DOE officials pointed out that one of their objectives has been to stimulate industrial capability. They noted that while some techniques or information may have been known to a few large companies, these techniques were largely developed in the oil and gas industry and are not widely known to be applicable to the development of geothermal resources. Hence, they believed such projects have helped reduce the technical and economic risks for new companies seeking to develop geothermal resources.

In response to our inguiries about the relative priorities of such projects, DOE officials told us that they have not established a formal mechanism for establishing priorities. In our report entitled "The Multiprogram Laboratories:" A National Resource for Nonnuclear Energy Research, Development, and Demonstration" (EMD-78-62, May 22, 1978), we previously noted that project managers, including those in geothermal development, did not have formal criteria for selecting projects. We reported that individual program managers select work to be carried out using their own informal criteria and 
undocumented technical judgments. We pointed out that clearly defined, uniform criteria were needed.

In an October 1977 report for DOE on the geothermal development program's project management system, the Mitre Corporation similarly reported that a rational project selection system is needed. Mitre reported, in part:

"The existing system allows substantial variation in the criteria/procedures for project/work unit selection, assignment, monitoring and control. These variations permit excessive inconsistency in the treatment accorded various individual projects/work units. In particular, the variability in current procedural standards allows project selection to depend heavily on the stature of the program manager who proposes each project."

DOE program officials advised us they have not yet estab1 ished a formal project priority system because they are just "getting on their feet" in managing the program. They pointed out, however, that they have made recommendations on leasing priorities to the Department of the Interior's Bureau of Land Management and, in January 1977, ERDA reorganized the program management structure to a "mission or iented team approach," which, in part, is designed to ensure that project priorities are established.

ERDA established a mission-oriented approach for commercializing four specific types of geothermal resources which ERDA chose to give priority to developing--sal ine hydrothermal, moderate temperature hydrothermal, high temperature hydrothermal, and geopressured resources. The rationale for choosing the hydrothermal resources was the potential for near-term use and the geopressured resources were chosen because of a 1 arge potential for use. Currently the mission-oriented approach in DOE is limited to hydrothermal.

In addition to using the mission-oriented approach, other actions have been taken to improve the monitoring and evaluation of ongoing projects. Mitre Corporation, under contract with DOE, has been providing information on the effect each ongoing project has on reducing geothermal energy's costs. Also under contract with DOE, Battelle Memorial Institute is using the information provided by Mitre to make an overall evaluation of how the research and development program is reducing geothermal energy's costs.

In addition, DOE has assigned project management responsibilities to its laboratories for three major geothermal projects. For these projects, the day-to-day decisions are 
made by the project managers, which reduce the program manager's workload. Hence, the program managers can devote more attention to carrying out their overall planning, monitoring, and evaluating responsibilities. Sandia Laboratories has been assigned project management responsibilitiss for a geothermal drilling and well technology research and development project; Lawrence Berkeley Laboratory for a scaling and brine control and reservoir engineering project; and Los Alamos Scientific Laboratory for a geothermal well logging project.

As a result of increased monitoring and evaluating efforts, in 1977 DOE began terminating projects. For the most part, terminated projects were those that had been judged to have little benefit to the geothermal development program. For example, one such termination involved a total flow turbine project which had already cost over $\$ 5$ million. This project was designed to demonstrate the technical feasibility of using total flow turbines for converting geothermal heat to electricity. After soliciting comments from industry and research representatives, and analyzing the project's benefits, problems, and potential effect, DOE decided that the project, even if it accomplished its optimum goals, would result in a more costly system for generating electricity than already available existing systems. Hence, DOE terminated the project in 1978 .

Although DOE's monitoring and evaluating of ongoing projects has improved, the project selection process has not significantly improved. Work projects are originated by a number of sources such as unsolicited proposals from industry, universities, and nonprofit organizations; DOE program managers; competitive procurements; and DOE laboratoriés., Depending on the originating source, these proposed projects flow through various review and approval channels in the DOE laboratories, field offices, and headquarters program offices. DOE's program office does not have an adequate mechan ism for providing current data on projects in the various stages of review and approval. Furthermore, proposed projects continue to be evaluated, selected, and approved by individual program managers largely on the bases of their own informal criteria and undocumented technical judgments. To ensure that proposed projects are routinely evaluated on a uniform basis prior to undertaking the projects, we believe a formal mechanism for setting priorities among projects is needed.

NEED TO ISSUE IMPLEMENTING REGULATIONS IN A TIMELY MANNER

Al though the Congress legislated a number of acts designed to stimulate accelerated geothermal development, delays 
in issuing implementing regulations have hindered development. Some of the legislative provisions could not be implemented until regulations were issued. Although the basic implementing regulations have now been issued, several of those that are designed to remove institutional barriers remain to be issued.

Although the Geothermal steam Act of 1970 was enacted 9 years ago, geothermal energy was not being commercially produced or used on Federal lands as of October 1979. The act authorized the secretary of the Interior to lease public lands for developing geothermal resources. Technical and economic considerations of developing geothermal resources are the principal reasons the public lands have not been developed. However, delays in issuing implementing regulations so that developers can lease the lands and begin to address these uncertainties with exploratory work have been a contributing factor to the slow progress to date. The implementing regulations which specify how private developers are to obtain leases were not put into effect until 3 years after the act was passed.

Although the establishment of ERDA as the lead agency for developing geothermal resources was to accelerate development, in part, by minimizing such delays, administrative delays persisted. For example the act authorizing Federal guarantees for geothermal loans became effective on september 3, 1974, but it took ERDA nearly 2 years to issue regulations implementing such guarantees. Thus, in the interim, ERDA could not accept or process any loan guarantee applications until the implementing regulations were published, and it was in mid-1977, more than 2-1/2 years after the act's passage, when ERDA approved the first guarantee.

Other Federal agencies have also been slow in issuing implementing regulations. The U.S. Geological survey took over a year to modify its regulations to reduce the paperwork and documentation required for lessees to conduct casual use geothermal operations (for example, geological surveys/ on leased lands. This regulation revision, which appeared to have been a simple procedural matter, had been recommended by the Interagency Geothermal Coordinating Councli in December 1976 , was issued in March 1978.

In addition, the Bureau of Land Management has a history of delays in developing and implementing regulations under the Geothermal steam Act of 1970. For example, it took the Bureau 3 years to implement the act's provisions. In this connection, the regulations covering leasing of Federal lands for geothermal exploration and development were not implemented until January 1974 . 
Since 1974, after a slow start, a substantial amount of Federal land has been offered and leased for geothermal development. About 815,000 acres, or 37 percent of federally-owned "known geothermal resource area" (KGRA) lands, have been so offered and, of this, over 444,000 acres were under ?ease as of June 1979. Another 2.25 million acres of other potentially valuable geothermal resource lands have also been. leased, 1.67 million of which were still under lease as of June 1979 . Most of the land leased has been under the jurisdiction of the Bureau of Land Management.

The Forest Service, which also manages a significant portion of Federal lands with high geothermal development potential, has made considerably less progress in leasing its lands, particularly in California.: While considerable interest has been shown by industry in leasing such lands in California, no lease sales have yet been held and no leases have been issued. Unless geothermal leasing is given higher priority within the Forest Service, we believe it could be a matter of concern for future geothermal development. 1/

The Bureau of Land Management has been attempting to further stimulate leasing of KGRA lands, however, the regulations needed to provide such a stimulus have taken the Bureau more than $2-1 / 2$ years to develop. Applications for leases of KRGA lands must be awarded competitively, while applications for leases of other Federal lands can be awarded noncompetitively. However, if two noncompetitive lease applications are filed in the same application filing period and overlap an area by 50 percent or more, the area is designated to be a KGRA land. Hence, the noncompetitive lease applications are rejected and can only be leased competitively. Experience has shown, however, when competitive bids have been subsequently sought, in a number of cases, no bids were made. Th is has prevented the leasing of some Federal lands and delayed the exploration and development of geothermal resources on such lands. Hence, the Bureau since June 1976 has been working to revise its regulations to permit the noncompetitive leasing of such lands when competitive solicitations result in no bids. The proposed regulations were finally developed by the Bureau in December 1978 and at the time of our review were being coordinated with DOE.

1 /Geothermal leasing activities are discussed in more detail along with recommendations aimed at improving Federal leasing in our report entitled "How to speed Development of Geothermal Energy on Federal Lands" (EMD-80-13, Oct. 26, 1979). 
The Bureau of Land Management also has a number of other regulations which took or are taking considerable time to develop and which are aimed at further easing implementation of the leasing provisions of the steam Act of 1970. These include

-a regulation to allow developers, with 1 imited capital, to defer a portion of their payments for leased lands;

- - a regulation to define when steam is produced for purposes of the 10-year readjustment term provided for in the Steam Act;

-a regulation to allow leases of public lands in tracts of less than 640 acres for small-scale, non-electric uses or for filling out contiguous blocks of geothermal areas being developed, and

--an amendment of existing regulations on work reguirements to allow a single developer, with several small contiguous leaseholds, to develop a single leasehold, but permit the work performed to be treated as expenditures for all the leaseholdings in the aggregated unit.

Regulations covering the above first three areas were finalized following a development period dating back to June 1976 and became effective Apri1 4, 1979. Regulations covering the last area have been under development by the Bureau also since June 1976 and were being coordinated with DOE at the completion of our review.

In commenting on the lengthy times involved, a Department of the Interior official stated that the development and issuance of these regulations have had low priority within the Department. This official stated that although some problems such as jurisdictional disputes have had to be resolved, the primary reason for the slow development and issuance has been delays in reviewing the proposed regulations. As an example, one regulation sat in an office within the Department for over a year before it was reviewed. It would appear, of course, that this is a Department of the Interior management problem and correction should have been an easy matter.

In discussing the slow issuance of implementing regulations with DOE officials, they told us that they have no formal system for following up on, or monitoring, the development of new regulations. Instead, they rely on inquiries and discussions regarding such regulations at Interagency Geothermal Coordinating Council meetings held every 3 or 4 months. They pointed out, however, that they do not follow up on the status of each of the regulations at each meeting. 
With the enactment of the National Energy Act of 1978 (NEA), I/ a number of new implementing regulations are required. We are concerned that if past history is repeated, it may be years before the full benefits of the new act can be realized. Only after implementing regulations are issued can the full benefits of the act be derived.

It is clear from the history of delays experienced by these various agencies in developing and implementing regulations that corrective actions are needed. Accordingly, we believe that management in each of the involved agencies should place greater emphasis on developing implementing regulations with the aim of issuing these regulations in a reasonable time frame. Although what constitutes a reasonable time frame should for the most part be determined on a caseby-case basis, we believe that generally such regulations should take no longer than 1 year.

RECENT LEGISLATION AIMED

AT STIMULATING GEOTHERMAL 'S

DEVELOPMENT AND USE

Since geothermal energy development is permeated with high technical and economic risks, many industry representatives stated that they need additional incentives before they would accelerate their efforts. The NEA provided a number of incentives which should help stimulate accelerated development. However, some uncertainty remains concerning the extent the incentives will promote more widespread use of geothermal resources.

Three of the five acts which comprise NEA have provisions aimed at increasing geothermal energy development and use. The first act, the Energy Tax Act of 1978 (P.L. 95-618, Nov. 9, 1978) authorizes intangible drilling cost deductions and a percentage depletion allowance for geothermal resources; provides tax credits for residential users of geothermal energy, and provides for a 10-percent business investment credit for certain types of alternative energy equipment, including geothermal energy equipment, with the exception of public utility property. A second act, the Public Utilities Regulatory Policy Act (P.L. 95-617, Nov. 9, 1978) gives the Federal Energy Regulatory Commission certain powers to order an electric utility to provide transmission and interconnection services

$1 / T h i s$ name is used to refer collectively to five separate acts dealing with energy matters. The acts, when first introduced in the House of Representatives, were all part of a single bill which would have been called "The National Energy Act of 1978." 
for geothermal powerplants that qualify as small power producers. The act also exempts from public utility regulation geothermal powerplants that qualify as cogenerators or small power producers. A third act, the Natural Gas Policy Act of 1978 (P.L. 95-621, Nov. 9, 1978) allows deregulation of geopressured methane.

DOE and many industry representatives believe that the tax incentives alone should result in an upsurge in exploration and development activity. Due to the long leadtimes involved in developing geothermal energy, however, it is doubtful that the NEA tax incentives will result in any significant increase in energy production before 1985. Increased activity in exploration and drilling could occur, but the energy resulting from these activities will probably not come on line until after 1985. However, there is considerable uncertainty from both DOE and industry representatives as to the extent or magnitude of the amount of energy that could ultimately come on line due to the many uncertainties and obstacles to geothermal development that remain to be resolved. The costs, returns, reliability, and ease of geothermal development will ultimately determine the course of development and use. Federal actions, such as those set forth in NEA, can help to improve these conditions.

In addition, several bills have been introduced in the 96 th Congress which would amend the NEA as well as the Geothermal Energy Research, Development and Demonstration Act of 1974, and the Geothermal steam Act of 1970. These bills would provide additional Federal initiatives and incentives aimed at further accelerating geothermal energy's development and use. In light of the current uncertainty surrounding the impact of NEA, we believe before any such proposed initiatives and incentives are enacted, DOE should make the Congress fully aware of the impact each could have on all phases of geothermal development and of the estimated annual costs involved. In this way, the congress would be in a better position to judge and decide on which initiatives or incentives are best for aiding geothermal development and use. 
CHAPTER 4

CONCLUSIONS, MATTERS FOR CONSIDERATION

BY THE CONGRESS, RECOMMENDATIONS, AGENCY

COMMENTS AND OUR EVALUATION

\section{CONCLUSIONS}

The Federal Government has been, "for some time, supporting efforts to accelerate the development and use of geothermal resources in this country. Although the Federal Government has spent nearly $\$ 500 \mathrm{milli}$ ion over the past 5 years, geothermal's development and use have proceeded slowly.

To develop these resources so they may be commercial, many technical, economic, environmental and institutional obstacles and uncertainties have to be addressed and resolved. Some progress has been made toward resolving them, but additional efforts will be needed. Until more progress is made on resolving these obstacles and uncertainties, geothermal resources can make only a limited contribution toward meeting U.S. energy needs.

While much of the failure to accelerate geothermal energy development and use can be attributed to the obstacles and uncertainties, some of this failure can also be attributed to problems in managing the program. DOE has taken some actions to improve the program, but much work remains to be done.

ERDA's and DOE's lack of a formal management system for setting priorities among projects often resulted in projects being undertaken which have proven to be of limited or no value. While DOE has been terminating some of the projects as a result of increased monitoring and evaluation efforts, the project selection process has not significantly improved. Work projects are originated by a number of sources such as unsolicited proposals from industry, universities, and nonprofit organizations; ideas from DOE program managers; responses by firms and other organizations under competitive procurements; and proposals by DOE laboratories. Depending on the originating source, these proposed projects flow through various review and approval channels in the DOE laboratories, field offices, and the headquarters program office. DOE's program office does not have an adequate mechanism for providing current data on projects in the various stages of review and approval. Furthermore, proposed projects continue to be evaluated, selected, and approved by individual program managers largely on the bases of their own informal criteria and undocumented technical judgments. 
To ensure that proposed projects are routinely evaluated on a uniform basis prior to undertaking the projects, we believe a formal system for setting priorities among projects is needed. Such a system would not only provide program managers with a better basis for selecting projects to be undertaken, but would ensure that all proposals are adequately considered on an equal basis with others.

t Delays in issuing implementing regulations have hindered geothermal development. DOE and the Department of the Interior have been slow in issuing regulations which are aimed at accelerating the development of geothermal energy resources. Some regulations have taken as long as 3 years to develop and issue. The Department of the Interior's Bureau of Land Management is still processing proposed regulations which it has been developing since 1976. The primary reason given for the lengthy time involved in issuing regulations, particulariy by the Department of the interior, has been the low priority given by management. Also little follow up is being given to the development of regulations. In adaition, DOE does not have a formal system for monitoring the status and progress of efforts to develop and issue such regulations. Hence, no mechanism exists to ensure that proposed regulations are not delayed due to a lack of attention or emphasis.

As the geothermal development program continues to evolve, legislative changes to the program can be expected. We are concerned that it may be years before many of the benefits of future legislation can be realized if past history is repeated in issuing the reguired implementing regulations. Hence, each agency involved with geothermal development should place greater emphasis on issuing implementing regulations in a timely manner. In addition, DOE, as Chairman of the Interagency Geothermal coorainating Council, should systematically monitor the progress being made in developing such regulations, and adopt a strong leadership role in ensuring that unnecessary delays are not encountered.

The NEA provided a number of incentives which should help stimulate accelerated geothermal development. However, there remains considerable uncertainty as to the extent or magnitude of the amount of energy that could result from these incentives.

MATTERS FOR CONSIDERATION BY THE CONGRESS

Several bills have been introduced in the 96 th Congress which would amend the NEA as well as the Geothermal Energy Research, Development and Demonstration Act of 1974 , and the Geothermal steam Act of 1970 . These bills would provide 
additional Federal initiatives and incentives aimed at further accelerating geothermal energy's development and use. In light of the current uncertainty surrounding the impact of NEA, we believe before any such proposed initiatives and incentives are enacted, DOE should make the congress fully aware of the impact each could have on all phases of geothermal development and of the estimated annual costs involved In this way, the congress would be in a better position to judge and decide on which initiatives or incentives are best for aiding geothermal development and use. In considering the magnitude or adequacy of support for geothermal energy, the Congress should be mindful that many major obstacles and uncertainties are impeding geothermal's development and use. Also, to some extent geothermal's slow development has been attributed to management problems.

Thus, in determining the appropriate level of support of Federal efforts to develop and promote the use of geothermal resources, the Congress should recognize that much greater focus is needed on removing these obstacles and uncertainties in order to realize geothermal's potential in the shortest possible time frame. In this connection, we are making a number of recommendations to the Department's of Energy and the Interior aimed at strengthening the geothermal program.

RECOMMENDATIONS TO THE

SECRETARY OF ENERGY

We recommend the Secretary of Energy:

--Establish a formal mechanism for setting priorities among research, development, and demonstration projects to ensure that proposed projects are routinely and uniformly evaluated and that priority attention is given to projects aimed at resolving the major uncertainties and obstacles to widespread geothermal use in the shortest possible time frame.

--Place greater emphasis on the timely issuance of implementing regulations and, as Chairman of the Interagency Geothermal Coordinating Council, systematically monitor each agency's progress in developing regulations and adopt a strong leadership role in ensuring that regulations implementing changes to the geothermal development program are developed and issued in a timely manner.

--At the time new Federal initiatives and incentives aimed at accelerating the development and use of geothermal energy are proposed either by the administration or by the Congress, determine the impact 
each could have on all phases of geothermal development and the estimated annual costs involved and submit each such analysis to the appropriate congressional committees for the ir use during consideration of those initiatives and incentives.

RECOMMENDATIONS TO THE

SECRETARY OF THE INTERIOR

We recommend the secretary of the Interior:

- - Follow up on the development of those regulations related to the leasing of Federal lands which were or have been in process for several years to identify and correct the problem and ensure that regulations are issued as soon as possible.

- Develop an internal system for monitoring the Department of the Interior's efforts to develop regulations
relative to geothermal energy. The system should provide checkpoints that would alert the secretary when such efforts are approaching 1 year in their development or are otherwise being delayed.

\section{AGENCY COMMENTS}

DOE, Interior, and the Environmental Protection Agency were each provided the opportunity to comment on a draft of this report. Interior's and the Environmental protection Agency comments were not received in time to be considered in preparing the final report. DOE's comments are discussed in the following sections.

DOE comments and our

evaluation

DOE stated that it basically agrees with our recommendations relating to improving mechanisms for setting priorities, and strengthening of the Interagency Geothermal Coordinating Council efforts in monitoring the issuance of regulations. However, it disagreed with our recommendation that DOE make the Congress more fully aware of the cost and impacts of various legislative proposals. DOE believes that it has already addressed comparative energy costs and estimates of the impact of RD\&D advances and tax incentives and found that geothermal is cost-competitive in most cases. DOE believes that delays for further analys is can only retard the leg islative process and result in slowing development or delaying decisions in the private sector to proceed because of lack of action tion on the legislative proposals. DOE also stated that current legislative proposals, endorsed by the administration, 
deal largely with the removal of regulatory and legislative barriers whose impact has been attested to by DOE and industrial and state government witnesses in congressional hearings and public meetings.

We agree with DOE's contention that elaborate analysis could delay the legislative process. However, we also believe that the Congress needs to be informed of the impact and costs of proposed initiatives and incentives in order to be in the best position to judge and decide on whether or not to provide additional initiatives and incentives. Current geothermal legislation before the Congress does, as DOE stated, deal largely with regulatory and legislative barriers; however, it also contains several provisions which would provide new Federal initiatives and incentives to aid geothermal development. We believe it would not take a major and elaborate analysis to provide the Congress with information on impacts and costs of these initiatives and incentives, especially since DOE should have most of this information available from its earlier analyses. We believe that the information that DOE could provide the congress, with 1 imited effort, would be extremely beneficial to the Congress.

We have performed numerous reviews of Federal efforts to develop new energy technologies over the past few years and have often found that information has been lacking on the impacts and costs that different Federal initiatives and incentives have on developing those technologies. We have also found and reported that some of these initiatives and incentives have been premature, have had limited success to date, and will most likely have little impact in helping solve the Nation's energy problems. We, therefore, remain convinced that there is a need for DOE to supply information on the impacts and costs of the proposed initiatives and incentives.

DOE stated that the report pinpoints an area of concern to DOE--project selection and prioritization--and actions are being taken to establish mechanisms for assuring that project duplication and reinvention does not occur and that a better prioritization of projects results. DOE stated that our criticism of project selection and prioritization focused on $R \& D$ projects representative of technology development activities. DOE, however, believed that the report failed to relate its changing emphasis toward commercialization and the organizational changes within DOE which have been implemented to focus on $R \& D$ requirements from the commercialization viewpoint. DOE also commented that not every R\&D project can be expected to result in a success and that Government funded R\&D projects are likely to elicit, under certain conditions, condemnation 
from the private sector when one's edge over competitors is being threatened.

We recognize that the Federal geothermal program encompasses all phases of geothermal development--research, development, demonstration, and commercialization-and that some R\&D projects, by their nature, will not be successful. In this regard, our review was concerned, however, with whether DOE had a formal system for setting priorities among all types of projects including $R \& D$ projects for technology development and $R \& D$ projects for commercialization purposes. We found no formal mechanism exists. We acknowledge the projects we cited in the report as having questionable success were representative of technology development activities, however, these projects were used as examples indicating the lack of and need for a formal mechanism for setting priorities among all projects relating to geothermal development. The report recognizes that DOE is involved with commercializing geothermal energy, and since DOE agrees with the need for a better system for prioritizing projects, we believe further elaboration of DOE's commercialization efforts is not needed.

In commenting on our draft report, DOE also pointed out that the report should include discussions on the Interagency Streamlining Task Force and its report on improving the Federal land management policy for leasing/permitting of public lands, the slow pace of leasing by the Forest service and Bureau of Land Management, and DOE's development of a project management and coordination monitoring system. We have included discussions of these matters in the report where appropriate. DOE also provided clarifying information on the implementation of its geothermal mission-oriented commercialization concept and information on its efforts to accelerate non-electric or direct use applications. We have also included this information in the report.

DOE also took issue with the report regarding our point on the amount of energy expected to come on line by 1985--1ess than 3,000 megawatts. DOE stated that a recent utility study and a recent DOE review of progress on electric geothermal power development support DOE's estimates of 3,000 megawatts by 1985. We have revised the report to reflect DOE's comment and stated our belief that there nevertheless remains much uncertainty about the amount of geothermal energy to come on line by 1985 .

While our report recognized that progress towards geothermal development and use has been made, we have also added DOE's points that (1) there has been much development activity that is expected to lead to utilization of geothermal energy; (2) because of the long leadtime required for development these 
activities have not yet produced power, although they do represent activities aimed at producing energy by 1985 ; (3) several major industry development projects are underway which should lead to electric powerplants in California, Utah, Nevada, and New Mexico by $1984 ;$ and (4) several of these projects have been accelerated through DOE's cost-shared drilling program, loan guarantees, demonstration program, and technology development. 


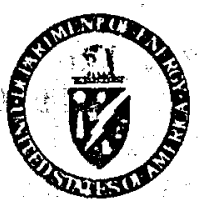

U.S. Department of Energy

Washington, D.C. 20585

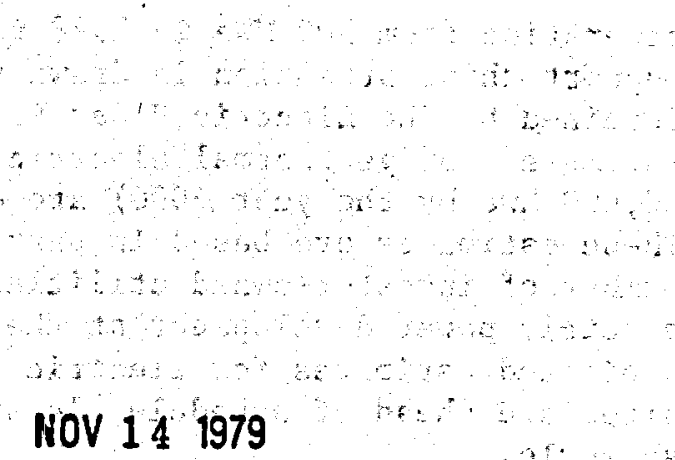

Mr. J. Dexter Peach, Director

Energy and Minerals Division

U.S. General Accounting Office

Washington, D.C. 20548

Dear Mr. Peach:

We appreclate the opportunity to review and comment on the General Accounting office (GAO) draft report entitled "Geothermal Energy:

Obstacles And Uncertaintles Impede Its W1despread Use." The Department of Energy basically agrees with the recommendations contained in the draft GAO report. Our vlews with respect to the text of the report are discussed below.

The statement in the report that there has not been an expansion or acceleration of use of geothermal energy 1s misleading. There has been a substantial amount of development activity that will lead to ut111zation. Because of the long lead time required for development, these activities have not yet produced power on-line, although they do represent activities that w111 produce energy by 1985 . Several major industry development projects are underway which will lead to electric power plants In California, Utah, Nevada, and New Mexico within the next two to five years. Several of these projects have been accelerated through DOE's cost-shared drilling program, loan guarantees, demonstration project, and technology developments.

The GAO report, in citing activitles In geothermal energy, did not address nonelectric or direct-use applications. A number of such activItles, Including a major district heating project at Boise, Idaho, and about 20 other nonelectric development projects, supported in part by: DOE, account for most of the nonelectric development now underway. These projects will result in a tenfold increase in nonelectric use by 1982, with further growth before 1985.

DOE also takes issue with the report regarding uncertainty in the extent and magnitude of the amount of energy that could come on-ilne by 1985 and in the amount of energy expected to come on-line before 1985. We have Identified profects that will increase the use of electrical 
generation from 500 MWe in 1978 to an estimated 3000 MWe by 1985. To support this, attention is drawn to the survey of investor-owned utilities obtained by The Electric Power Research Institute (EPRI). The EPRI estimates for geothermal electric use ( 3000 MWe by 1985 and more than 20,000 MWe by the year 2000) are consistent with the DOE estimates. These estimates are based in part on an annual survey of alimited number of investor-owned utilities. A recent DOE review of progress on electric power development at the 27 sites that constitute DOE's 1985 projected estimates for electric power on-line shows that 10 of these sites are ahead of schedule, 14 are on schedule, and only 3 are behind schedule.

Relative cost of geothermal versus other forms of energy was considered by DOE. We have addressed comparative energy costs and estimates of the Impact of RD\&D advances and tax incentives and found that geothermal is cost-competitive in most cases. Demand for electricity has been determined to be sufficient for the projected plants included in our study. We therefore disagree with the suggestion that DOE make the Congress more fully aware of the cost and impacts of various legislative proposals. Delays for further analysis can only retard the legislative process and result in slowing development or delaying decisions in the private sector to proceed because of lack of action on the legislative proposals. These current legislative proposals, endorsed by the Administration; deal largely with the removal of regulatory and legislative barriers whose impact has been attested to by DOE and Industrial and state. government witnesses in Congressional hearings and public meetings. The continued existence of these barriers has not been demonstrated to be of value, and their removal should not require elaborate justifications.

The draft report also fails to mention the effort of the Streamlining Task Force or Its Report of Recommendations for improving the Federal Land Management Policy. for the leasing/permitting of public lands. The legislative proposals before the Congress are based on the Task Force findings and represent concerted interagency effort with private sector concurrence. GAO reports on a history of delays in developing and implementing Bureau of Land Management (BLM) regulations under the Geothermal Steam Act and the slow pace of leasing without specific reference to the eligible amount of U.S. Forest Service (FS) lands for which geothermal leases have not been issued.

The slow pace of processing BLM/FS non-competitive lease applications and FS competitive lease sales is not discussed in the report. However, we agree that the Interagency Geothermal Coordinating Council's (IGCC) efforts in monitoring delays in issuance of regulations by DOI should be strengthened. But consideration of the impact of the lack of continuity in IGCC Chairmanship ( 5 changes in 4 years) should be reflected in the final GAO report. 
A project management and coordination monitoring system is being designed. Meetings with the principal input centers, to implement the system, have been held. The System should become operational during Fiscal Year 1980.

The GAO criticism of project selection and lack of prioritization 18 focused on DOE geothermal R\&D projects representative of technology development activities. The report falls to relate changing emphasis toward comercialization (market assessment/penetration, planning economic analysis, outreach) and the organizational changes within DOE which have been Implemented to focus on R\&D requirements from the * commerclalization viewpoint. The driving force behind selection of R\&D projects for technology development is commercialization. Development of economically viable resources and components that can show costbenefits and effectively 1mpact on energy development to supplant Imported fossil fuel are the primary targets. Not every R\&D project can be expected to result in success any more than every deep exploratory test will prove a new reservolr. It should also be recognized that the Individual government funded R\&D projects are likely to elicit from the private sector condemnation, particularly when proprietary developments held by an opponent to government $R \& D$ are being jeopardized and his edge over individual competitors is belng threatened. These arguments notwithstanding, the GAO report does pinpoint an area of mutual concern to DOE and actions are being taken to establish mechanisms for assuring that project duplication and relnvention does not occur and that a better prioritization results.

The report also makes reference to the establishment of mission team leaders to manage a type of geothermal resource. Currently the missionoriented commerclalization of geothermal resources is limited to hydrothermal type resources. The Geothermal/Hydrothermal Program activity is being implemented and monitored in the DOE Regional offices and fleld operation offices. The furisdictional breakdown of activity with the Regional office is on a state-by-state basis, since in most instances this is the largest geographical entity that can be handled politically and legally considering the variation in definition of the resource and attendant legal, regulatory and environmental constraints on development.

We appreciate your consideration of these comments in the preparation of the final report and $w 111$ be pleased to provide any additional information you may desire in this matter.

Sincerely,

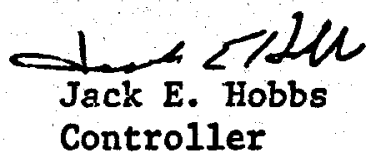

(307070) 
To the President of the Senate and the Speaker of the House of Representatives

This report discusses the obstacles and uncertainties impeding the widespread use of geothermal energy. It includes a perspective on geothermal energy's development and potential, and a discussion of Federal actions needed to help accelerate geothermal development and use.

Copies are being sent to the Director, Office of Management and Budget; the Secretary of Energy; the Secretary of the Interior; the Secretary of Agriculture; the Administrator of the Environmental protection Agency; and interested Members and Committees of the Congress.

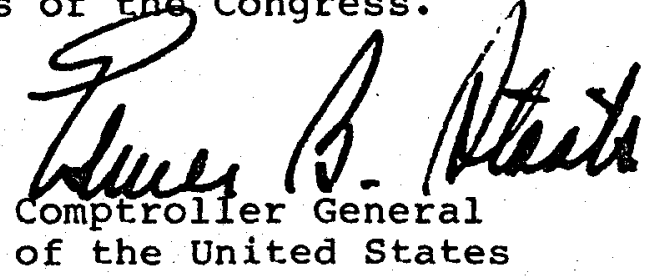

DISTRIBUTION OF THIS DOCUMENT IS UNLIMITED 
Single copies of GAO reports are available free of charge. Requests (except by Members of Congress) for additional quantities should be accompanied by payment of $\$ 1.00$ per copy.

Requests for single copies (without charge) should be sent to:

U.S. General Accounting Office

Distribution Section, Room 1518

441 G Street, NW.

Washington, DC 20548

Requests for multiple copies should be sent with checks or money orders to:

U.S. General Accounting Office

Distribution Section

P.O. Box 1020

Washington, DC 20013

Checks or money orders should be made payable to the U.S. General Accounting Office. NOTE: Stamps or Superintendent of Documents coupons will not be accepted.

\section{PLEASE DO NOT SEND CASH}

To expedite filling your order, use the report number and date in the lower right corner of the front cover.

GAO reports are now available on microfiche. If such copies will meet your needs, be sure to specify that you want microfiche copies. 
AN EQUAL OPPORTUNITY EMPLOYER

UNITED STATES

GENERAL ACCOUNTING OFFICE

WASHINGTON, D.C. 20548

of fTcLal BUSTMESS

PENALTY FOR PRTVATE USE, 8300 postáce and reEs pato

U. 8. Gexeral accouxtruc of rice

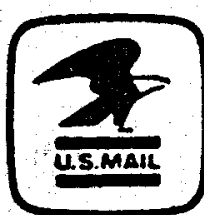

THIRD CLASS

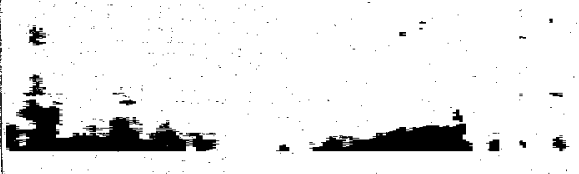

ERDA Teehnlcal Informatzon

Center 667

P.0. Box 62

Opkridge, Tenn- 37830 